\title{
The Three Faces of the Korean Nation
}

\author{
By Étienne Girouard ${ }^{*}$
}

This article proposes a theory on how national genetics may solve the theoretical maelstrom engulfing the study of nations in Korea. The national genetics theory is firstly presented with the concepts of national genotype, national genotypic heritage, national chromosomes, national genes and national phenotypes being defined. National genetics is then applied to the heterodox case of Korea, where three different nations are often confused due to the striking resemblance between them. The themes of imperialism and political legitimacy are seen as sociopolitical chromosomes structuring Korea's continually evolving national genotype. It will be shown that these chromosomes are part of a national genotypic heritage that has framed all three national phenotypes of Korean modern history: the republican nation, the revolutionary nation and the developmental nation. Finally, this article will demonstrate how national genetics helps resolve previous antagonistic claims made about nations, nationalism and ethnicity in Korea.

Keywords: elite nationalism, genetics theory, imagined communities, imperialism, Korea

\section{A Theoretical Maelstrom}

There are a myriad of distinctive features that help single out the Korean Peninsula as a compelling case study in the field of nations and nationalism. On one hand, proponents of ethno-symbolism see the former state of Koryo (935-1392) as a typical but rare case of a pre-modern nation (Ozkirimli and Grosby 2007: 528, Smith 1998: 190). On the other hand, primordialists, utilizing a national history and celebrating the alleged ethnic, cultural and linguistic homogeneity of a people tightly bound to its peninsula, support the argument that only one Korean nation has existed through the ages (Duncan 1998: 198). Alternatively, some scholars observe the historical permanence of cultural traits that distinguish Korean ethnic group from other ethnic groups in East Asia to invoke the existence of a strong protonationalism, assuming the notion that the nation ultimately remains a modern phenomenon (Hobsbawm 1992). However, most - if not all - modernist theories of the nation fail to provide a model to explain the Korean case, which remains well beyond the context of Western modernization (Shin 2006: 12). Finally, constructivists, focusing on everyday practices, refuse to see the Korean nation as a unique

${ }^{*} \mathrm{PhD}$ Candidate, University of Quebec, Canada. 
phenomenon that is constrained by ethnicity schemes (Kang 2012). Indeed, these scholars claim that the last century of Korean history has led to different nation-building processes where several imagined communities have flourished on the Peninsula. The questions raised by the phenomenon of the Korean nation have not only brought equivocal responses, but they have also shown that in the study of nations and nationalism, Korea fits among the rarest and most heterodox cases. The study of the Korean national phenomenon is also known to be the victim of numerous methodological biases, further confusing this already bewildering case (Shin 2006: 19). The theory of national genetics will be put forward below in order to expose and address the multiple theoretical and methodological flaws obscuring a proper comprehension of nationhood in Korea.

\section{National Genetics}

While the tragic memories of Nazism, eugenics and genocides are still fresh in people's minds, primordialist claims - in addition to other theories that aim to reify the nation based on genetics - continue to generate sharp criticism (Eller and Coughlan 1993: 199, Ozkirimli 2003: 351-4). However, the world of genetics has now changed. While the universe of genetics once evoked an absolute biological determinism, the recent emergence of genetic engineering reveals that change is now possible, instigating a transformed perception of reality in this field. The modification of a specific genotype may indeed be carried out by genetic engineering, but such an undertaking is only possible if the engineering process takes into account the limits set by the chromosomal structures of a particular species, biological arrangements where the genes express themselves ${ }^{1}$.

National genetics also has its share of engineers. While creating imagined communities, political elites use nationalist discourses to invent, reproduce, obliterate, select and alter national genes such as: myths, heroes and symbols. By doing so, national engineers are truly modifying the national genotype. This type of national engineering is conditioned and limited by factors that shape the morphology of a national genotype. Playing the role of a sociopolitical matrix, the chromosomes of a national genotype provide the narrow framework within which the creative work of the national engineers will take place. It is from this source where national phenotypes - corresponding to historical imagined communities - arise. These vary contingently under the influence of environmental factors such as the work of the elite ${ }^{2}$. Represented as the frame from which national phenotypes are built by their engineers, this chromosomal heritage constrains and structures the phenotype expression of national genes.

\footnotetext{
${ }^{1}$ For instance, a human being has between 20,000 to 30,000 genes that are all located on twenty-three pairs of chromosomes.

${ }^{2}$ Besides elite engineering, other environmental factors such as history and structures also mold national phenotypes. It must be stated that these factors are not the subject of the present analysis.
} 
Thus, the national genetics theory aims at explaining how national phenotypes appear in all their variety while, at the same time, showing how a common national genotypic heritage is the main informational prism through which national engineers are thinking of imagined communities.

Within this theoretical framework, an analysis of a nation must first begin through the characterization of its related national genotype. This is achieved by focusing on the touchstone of its national genotypic heritage, namely its chromosomal substrate. Moreover, national genetics allows us to explain how a national genotype heritage connects all of Korean nations together, creating an unmistakable sense of parenthood between them. Hence, by employing the term 'nation' as defined by Benedict Anderson (1996), this paper acknowledges the existence of three imagined communities in modern Korea: the republican nation (1919-1945), the revolutionary nation in North Korea (DPRK) (1950-2013) and the developmental nation in South Korea (ROK) (1961-2013). Unfortunately, scientists too often mistake these three national phenotypes because of their common national genotype heritage.

\section{Republican Nation}

After over a century of nationalist rhetoric, it was the 1919 republican nation that was entrusted with the double objectives of defeating imperialism and founding the political legitimacy of the Korean State based on a new republican order that broke with the long-lasting principle of autocracy and the social and political inequalities that were consubstantial to the Korean Ancien régime and the ongoing Japanese rule. Hence, this investigation sets out to examine below how the two chromosomes of imperialism and political legitimacy provided a blueprint of the first national phenotype of Korean history. In addition to the role played by the elites and history, this phenotype as a structure - was a key factor that contributed to fostering the national genotype that framed Korean's imagined communities in the following century.

Imperialism is the first national chromosome that will be studied here. It will be shown that many Korean nationalist discourses occurring between the late eighteenth century and the first two decades of the twentieth century discourses that led to the first Korean nation - were framed by this chromosome. Raising the specter of foreign threats helped social elites undertake popular mobilizations around national claims. However, these processes were often isolated and uncoordinated, being sporadic and regionally confined. The chromosome of imperialism revealed itself through three specific historical junctures: the Chinese, Western and Japanese periods of domination.

As a consequence to some of the nationalist discourses held during the eighteenth and the nineteenth centuries, many popular movements arose demanding an end to the Choson Dynasty's pro-Qing policies, at the time accused of drowning Korea into conservatism and stagnation. Moreover, the Opium Wars and the resulting unequal treaties of Nanjing and Tianjin added to the colonial dismemberment of China and rattled old certainties. The Middle 
Kingdom's neo-Confucian political doctrine was now seen as a dangerous weakness in a changing world where modernizing imperialist states such as France, England, Germany and Russia were gaining substantial leverage over traditional powers. Nationalist Sirhak thinkers ${ }^{1}$ such as Hong Tae-Yong, Pak Chi-Won and Chong Yag-Yong abundantly criticized the sino-centered $\mathrm{Hwa-yi}$ official ideology of the Choson in their writings.

Regarding the formation of nationalist discourses, the Western domination exerted on Korea operated most decisively in an indirect manner. For Korean nationalists, Western imperialism was also lived through the experiences of neighboring China. The Korean social elite that put forward the Tonghak doctrine were convinced that peasants would have to be brought together in a new national spirit to avoid following China's destiny of collapse under Western imperialist subjugation. However, the downfall of neighboring China should not obscure the developments related to actions carried out by Christian missions operated on Korean territory. Cultural imperialism associated with these missions has been criticized by several nationalist leaders. For example, nationalist Ch'oe Che'u, founder of the Tonghak doctrine, loudly proclaimed that Christianity was nothing but the spiritual face of Western imperialism. Furthermore, it must be stated that criticism of Western colonialism certainly extended beyond the issue of the Christian missions. For instance, in the late nineteenth century nationalist discourses emanating from the Independence Club and from Seo Jae-Pil's All People's Congress all condemned the proRussian policies of King Kojong.

Finally, it was Japanese rule itself that fueled the plethora of nationalist discourses that directly led to the emergence of the republican nation of March 1919. For example the Wijong choksa movement of traditionalist elites ${ }^{2}$ took a strong stance against Japan, praising Confucianism. In addition, Tonghak, a nationalist doctrine also quickly emerged to lambast Japanese imperialism. Furthermore, the Virtuous Army against Japanese Occupation was also an active forum where nationalist discourses that soon gave birth to the Korean nation were diffused throughout society.

The issue of political legitimacy often plays a prominent role in the study of the national phenomenon (Gellner 1989: 77). The second chromosome was included in Korea's national genotype and political legitimacy undeniably framed the republican nation. As a result of the political vacuum caused by the 1910 collapse of the Choson Empire, nationalist discourses began focusing on theorizing political legitimacy, putting aside autocratic rule to praise a new republican model. Through the popular sovereignty that it advocated, the nation was closely associated to political legitimacy. The nation became central to the nationalist discourses striving for political independence while Korea, as the forgotten child of Versailles, remained under the militarist rule of Japan.

\footnotetext{
${ }^{1}$ Sirhak is a social reform movement against the neo-Confucianism orthodoxy of the Choson Dynasty. This movement took place between the seventeenth and the nineteenth century.

${ }^{2}$ Wijong Choksa is a conservative intellectual movement of the late nineteenth century against foreign imperialism and Christianity.
} 
The nationalist discourses that emerged during the Choson Dynasty's last decades emerged mainly from both peasant and intellectual elites. Built around claims for political legitimacy, these discourses often generated sporadic episodes of social contestation that focused on demands for political change. The influence of Ch'oe Che'u, nationalist of Tonghak, thought over the peasant revolts of 1894 and demonstrated how these new ideologies were able to foster massive popular uprisings. Based on the anti-imperialist theses of Ch'oe, this peasant rebellion put forward a violent critique of the neo-Confucian political hierarchy, an ideology seen as entangled in a total lack of political legitimacy while being unable to promote equality among its own people. Tonghak nationalism brought the political legitimacy issue into the limelight of the Choson political scene by demanding an end to feudalism in Korea.

Before the establishment of the Japanese protectorate over Korea in 1905, nationalist rhetoric was closely associated with political legitimacy through a critique of the Choson Dynasty's archaic political structures. However by 1905 , the issue of legitimacy became even more prevalent in nationalist discourses as it was now connected to the critique of the Japanese occupation. Intellectual elites from the Patriotic Movement for Korean Enlightenment placed the modern principle of republican sovereignty at the core of their nationalist aspirations. The subsequent 1910 annexation of Korea by Japan also galvanized this trend. The collapse of the old Korean dynasty - where political legitimacy was derived from a neo-Confucian system of rites and beliefs created the need for a new culture of legitimacy. Benedict Anderson also stressed that nationalist doctrines often play a crucial role in the wake of the modern decline of religious thought, a situation to which the waning of Korean neo-Confucianism could be closely related. The doctrine of Wilsonian internationalism that put political legitimacy, popular sovereignty and the nation all together gave the final push. By March 1919, the international context following the "Fourteen Points" enunciated at the Paris Peace Conference two months earlier led to an intensification of nationalist discourses that began emphasizing the issues of imperialism and political legitimacy to unprecedented levels. The national rhetoric now transcended into society by reaching most of the masses. The republican nation emerged from this quest for freedom and self-determination and this imagined community was strongly anti-imperialist and truly republican.

\section{Revolutionary Nation}

Engineered in the 1950s in the DPRK, the Korean revolutionary nation shares a common genotypic heritage with the republican nation. It was asserted above that an imagined community and comes to reality when nationalist discourses reach most of the masses. Unlike the republican nation, the revolutionary nation was materialized very quickly. The North-South antagonism generated by the Korean War (1950-1953) proved fertile ground where nationalist discourses - propagated by the new communist state - gained 
an extraordinary persuasive force. Imperialism and political legitimacy continue to be very present in the DPRK's nationalist discourses and once again these two issues continue to frame the emerging nation. How these two sociopolitical chromosomes came to frame the creative work of DPKR's elites in their making of a new nation will be examined below.

It has already been established that the chromosome of imperialism belongs to the common genotypic heritage of the Korean imagined communities. The case of revolutionary nationalism is no exception to this rule. This new form of ideologically driven imperialism will introduce how international system political bipolarity created the conditions for the existence of this new Korean nation.

The division of the world between the Allied forces encouraged the Union of Soviet Socialist Republics (USSR) and the United States of America (USA) to consolidate geographical areas under their respective influences. The DPRK resulted from this new type of imperialism. In 1945, Korea was divided into two states that were immediately put under the strict control of the designated occupying forces. The Soviet army occupied the North of the peninsula and ensured that the development of social and political institutions were favorable to their own interests. The development of the Workers' party of Korea appropriately illustrates how the Soviet control over national institutions likely took place.

Soviet imperialism has exercised a huge influence over the constitution of the new regime. It not only fostered the first DPRK nationalist discourses, but it also steered the DPRK towards following a fratricidal path during the Korean War (1950-1953). The warmongering spirit resulting from this war became an additional opportunity to spread nationalist discourses among the masses. These discourses portrayed the USA rule over South Korea as another form of imperialism. Initially, the Korean War was far removed from being a grassrooted phenomenon. Under the imperialist guidance of the USSR, the North Korean political elite progressively infused the society with numerous nationalist discourses focusing on the threat of USA imperialism. It was under the action of these discourses that a process of group formation took place, effectively leading to the necessary level of groupness where crystallization of an imagined community became possible (Brubaker 2002: 171). This new imagined community became the DPRK's anti-imperialist and anti-American revolutionary nation. Driven by the whims of Moscow and directed against Washington, the revolutionary nation embodied the gamut of political frictions that were present between these two great imperialist powers during the Cold War. Thus, the DPRK's nation resulted to an ideological matchup, where a type of imperialism condemned the actions of its principal rival.

Similarly to the case of imperialism, the theme of political legitimacy, the second of Korea's national chromosomes to be analyzed in this article, is also present at the core of the revolutionary nation. The main objective of the first nationalist discourses that paved the way for the Korean War was to show that only the DPRK was truly authorized to defend and represent the whole Korean peninsula. Portrayed as a puppet of USA imperialism, the DPRK insisted that 
Syngman Rhee's comprador regime that prevailed in the Southern part of the peninsula must be defeated. Also, it must be stated that the Juche-based nationalist discourses ${ }^{1}$ all gave a prominent role to both the Workers' party of Korea and to the Great Leader Kim Il-Sung. As the product of an official nationalism, the revolutionary nation first and foremost sought to ensure the political legitimacy of the new rulers. In subsequent decades, Kim Il-Sung and Kim Jong-Il relentlessly resorted to the same nationalistic ideology in order to reassert the vital importance of their reign as they both attempted to personify their political power.

To sum up, the revolutionary nation has been primarily engineered through the demonization of the out-group located on the other side of the border. Could a peninsula such as the one studied here - once the breeding ground of a single nation, now divided into two states - have produced different results? The usefulness of the nationalist discourses consisting of Seoul-bashing lay primarily in the fact that the political elites sought desperately to establish their own political legitimacy by highlighting the lack of legitimacy attributed to their main opponent. The quest for political legitimacy was indeed highly Manichean. On another note, it must also be stressed that revolutionary nationalism quickly incorporated ancestral heroes as mythical figures that were used for comparisons with the DPRK's political figures. For example, the god Tangun, the mythological founder of Korea, became in vogue again in Kim's DPRK. These heroes were introduced to the masses as great revolutionaries in their respective eras. This advancement of their transformed role was highly effective in empowering the political legitimacy of DPRK's elites.

\section{Developmental Nation}

Like the revolutionary nation, the developmental nation emerged in the context of the partition of the Korean peninsula. The ROK held democratic elections in 1948 after approximately three years of direct USA control. The Korean War (1950-1953) broke out two years later. ROK's society came out severely weakened from this conflict. Economic dislocation went hand in hand with a growing sense of anomie within Korean society. During the 1950s, President Syngman Rhee departed considerably from the ROK's democratic ideals, becoming the main promoter of an authoritarian state where privileges were distributed among the newly created Liberal party. Rhee's party ended up governing in an egocentric manner, blindly pursuing its supporter's own interests. The party also showed a strong commitment towards Washington's anti-communist policies by welcoming USA military bases on ROK territory. As a result of these policies, the ROK's political elite ignored an entire society that was left in total decay and that denied the possibility of imagining the nation.

\footnotetext{
${ }^{1} J u c h e$ is the official ideology of North Korea.
} 
The 1961 military coup led by General Pak Chung-Hee completely transformed the ROK experience. Overthrowing the short-lived 1960 born Second Republic, this new authoritarian regime implemented policies that fostered the required conditions for the emergence of the nation. Like Rhee beforehand, Pak flooded society with anti-communist nationalist discourses in order to establish its new political legitimacy. However, this time, calls for the nation were no longer left unanswered. Nationalist discourses generated mass mobilizations through the expansion of modern media and the establishment of the chaebol conglomerates that became the flagship of the developmental state. Embodying the nation, these conglomerates were and continue to be tightly interwoven. The idea of unity they evoked in the minds of Koreans finally allowed most of the masses to imagine the nation. From a Gellnerian perspective, it must also be stressed that the social mobilization generated by the process of accelerated industrialization was also an important contributing factor behind the consolidation of national groupness. In addition, the educational system also became a place where the national culture was inculcated and reproduced, becoming another important pillar of the developmental nation.

An examination into how the national genetics theory allows us to uncover the chromosomes that connect Korea's national genotype with the developmental nation is useful. Once again, both imperialism and political legitimacy issues can be seen as sociopolitical chromosomes lying at the core of the national genotype. How these chromosomes have framed the developmental nation will also thoroughly be examined below.

The developmental nation is based primarily on the implementation of state capitalism. Therefore, it is fundamentally anti-communist. The fact that it presents itself as an organic nation also induces a strong aversion towards Marxist-Leninist derived forms of universalism. Indeed, it is not surprising that this type of ethnic-based groupness becomes highly reactive when reflecting over the tragedy of Korea's partition. The developmental nation believes that Soviet imperialism is solely responsible for Korea's national divide. Since the 1961 coup, the economic modernization advocated by developmentalist nationalists was advanced to act as a bulwark against the Soviet imperialism that had already conquered Pyongyang. The developmental nation also fed into General Pak's anti-communist Pangong ideology. The new nationalists thus depicted communism as the most dangerous type of imperialism. In addition, it must be stated that developmentalist nationalists interacted smoothly with USA imperialism. In other words, Moscow's imperialism was not alone in shaping the developmental nation, since Washington indeed identified South Korea as an important country to be controlled in order to achieve the containment of China. Hence, the USA went to great political and economic lengths to stimulate the ROK's anti-communist hatred.

Political legitimacy is another issue that must be considered in order to reach a clear understanding of the developmental nationalist discourses. This anti-imperialist and anti-Communist nationalism sought to legitimize General Pak's military rule by placating dictatorship as the only effective way to assure 
the survival of the nation. Simply put, developmental nationalism left Koreans with only two choices: to be either ruled under communist savagery or to accept Pak's benevolent autocracy.

Furthermore, Pak's endless need for legitimacy was rooted in the way he seized power. Indeed, the usurpation of democratic power that propelled him towards becoming head of the state might well explain why the developmentalist nationalist discourses, aimed at establishing its political legitimacy, were so useful. Like Kim Il-Sung, Pak used heroic figures to cultivate his regime's legitimacy. It is not surprising therefore that old heroes such as Admiral Yi Sun-Sin were incorporated into the nationalist liturgy. By elevating Yi to the highest national ideal, Pak exploited the heroic virtues of the sixteenth century Admiral who had bravely defended Choson against former Japanese invaders for his own benefit. Ultimately, when Pak proclaimed himself as the most vital bulwark against an inescapable communist invasion, he made sure that his people praised him, as if he was a modernized version of Yi Sun-Sin.

The developmental nation was renegotiated during the 1980s. The groupness process as understood by Brubaker cooled considerably at times (Brubaker 2002: 170-171). By the 1980 Gwangju uprising, it was clear that the encoding of the nation became the object of a struggle between both military and student elites. The student driven minjung movement ${ }^{1}$ was successful in defeating the military regime, and the onset of democracy brought a reconfiguration of the norms establishing political legitimacy. Further along, the emergence of a civilian government in 1987 and the financial crisis of 1997 were two major events that also led to a redefinition of the developmentalist model.

Despite all these sources of social upheaval, the developmental nation remains alive and well today, with the Segyehwa policy ${ }^{2}$ attempting to reconcile the imperatives of state capitalism with the requirements of globalization. Issues of imperialism and political legitimacy remain at the core of a developmental nationalist discourse that continues to abide by the principles engraved in Korea's national genotypic heritage. For example, the democratic elites of the Sixth Republic at times echoed student antiAmericanism not only by denouncing USA imperialism, but also by condemning the World Bank and the International Monetary Fund as new types of financial imperialism that were responsible for the 1997 crisis. Furthermore, by promoting coexistence between democracy and state capitalism, the renewal of developmental nationalism gives political powerholders a new form of legitimacy as emerging generations decreasingly fear for the specter of a new Korean War.

\footnotetext{
${ }^{1}$ The minjung movement of the eighties gave birth to many pro-democratic demonstrations that were held against the authoritarian military rule of Korean politics.

${ }^{2}$ Segyewha was a foreign policy of internationalization launched by President Kim-Young-Sam in the nineties.
} 


\section{Theoretical Contributions of National Genetics}

The national genetics theory allows us to not only portray how the three imagined communities of modern Korea can be identified as national siblings, but also reveals how kinship links these imagined communities to a national genotype heritage fostered by the socio-political context within which they arose. Moreover, the creative work of the Korean elites, as true carvers of the nations, has always been constrained by the existence of a national genotypic heritage displaying a particular sociopolitical nature. The ensuing national engineering processes have hence been shaped by chromosomal factors such as imperialism and political legitimacy. These factors were not only encouraged by structural events such as emerging national phenotypes and preserved by a particular course of historical progression, but they were also sustained over time by strategic choices made by the elite. Furthermore, imperialism and political legitimacy are both tightly associated with Korea's entry into modernity. They are also closely related to Korea's social and political modernization processes.

In conclusion, national genetics theory contributions will be briefly summarized. First, it reconciles the modernist theories of the nation with the Korean case. It allows researchers to avoid the multiple biases generated by Western-centered and Euro-centered theoretical perspectives common to mainstream modernist theories. The National genetics theory suggests that the roads leading to modernity are plural and thus cannot be restricted to those previously travelled by Western societies. National genetics theory also portrays Korea's progression into modernity by demonstrating how its development has been framed by the structuring power of two key factors: the occurrence of an imperialist driven state of turmoil and the almost concomitant search for new modes of political legitimacy.

Second, the national genetics theory prevents researchers from falling into the trap that has handicapped most culturalist theorists, namely the temptation to forge a particularistic metaphysic of the nation - which is built on ethnicity as a result of the modernist failure to successfully explain the Korean case. Unfortunately, having the tendency to reify the nation, these ahistorical theories have often put forward a litany of claims that underestimate the influence that elites and structural factors may have had over the formation of the imagined communities.

Third, the national genetics theory preserves the idea of continuity, which is central to culturalist theories, by anchoring the nation in the sociopolitical and historical longue durée characterizing the national genotype. Moreover, the national genotypic heritage concept helps resolve an illusion that distorts perennialist theories, namely their mistaken claim regarding the timelessness of the Korean nation. With regard to identities, the national genetics theory acknowledges a form of continuity through the unveiling of a national genotypic heritage concept, but remains mindful of a set of groupness processes - under which various imagined communities will form and disappear over time. In other words, the national genetics theory is based on 
the idea that a national genotypic heritage could be used to explain how environmental factors, such as history, structures -including previously formed national phenotypes - and elite strategies, may lead to various, but similar national phenotypes. Paradoxically, these phenotypes are truly diverse and simultaneously deeply intertwined, displaying astonishing similarities.

Fourth, the national genetics theory censures immoderate constructivist claims about the seamlessness of identity manipulation. Accounting for sociopolitical longue durée and emphasizing structures allows for a counterbalancing of the strategic role played by the elites. Hence, the national genetics theory successfully curtails exorbitant levels of identity volatility often criticized for exaggerating theoretical instrumentalism.

Fifth, as demonstrated through the interaction of imperialism and political legitimacy in the Korean analysis, national genetics theory allows us to capture the amazing power of attraction towards adopting national discourses that is often a consequence of contact with external nations and nationalism. Although the national idea was transported to Asia by the forces of Western imperialism, it was also quickly imported on Korean soil by local elites who were seeking to foster mass mobilization in order to sustain both their struggle against imperialist policies and also their quest for political legitimacy. In other words, imperialist powers provided Korean elites with a new conceptual toolbox that helped them design their political claims against colonial rule.

Ultimately, as a middle range theory, the national genetics theory could prove to be a fair compromise between overly broad claims made by modernist theorists and disproportionately narrow culturalist perspectives. The dispersion of this theoretical model would also allow researchers to gather conclusive evidence about the scientific usefulness of a national genotypic heritage concept, an approach that has helped us reconcile two theoretical poles that were strongly retained in an antagonistic logic in most studies devoted to the national phenomenon in Korea. The National genetics theory allows us to tune our analytical gaze in accordance to a particular context while at the same time it provides political scientists with a very valuable analytical framework that achieves a high, but still reliable, level of generalization.

\section{References}

Anderson B (1996) L'imaginaire National: Réflexions sur l'origine et l'essor du Nationalisme [National Imaginery: Reflections on the Origin and Development of Nationalism]. Paris: La Découverte.

Brubaker R (2002) Ethnicity without groups. European Journal of Sociology 43(2): 163-189.

Duncan J (1998) Proto-nationalism in Premodern Korea. In S-O Lee, D-S Park (Ed.) Perspectives on Korea: 198-221. Sydney: Wild Peony Press.

Eller JD, Coughlan RM (1993) The poverty of primordialism: Demystification of ethnic attachments. Ethnic and Racial Studies 16(2): 183-199.

Gellner E (1989) Nations et nationalisme [Nations and nationalism]. Paris: Payot. 
Hobsbawm E (1992) Nations et nationalisme depuis 1780: Programme, mythe, réalité [Nations and nationalism since 1780: Program, myth, reality]. Paris: Gallimard.

Kang JW (2012) The disciplinary politics of antagonistic nationalism in militarized South and North Korea. Nations and Nationalism 18(4): 684-700.

Ozkirimli U (2003) The Nation as an artichoke? A Critique of ethnosymbolist interpretations of nationalism. Nations and Nationalism 9(3): 339-354.

Ozkirimli U, Grosby S (2007) Nationalism Theory Debate: The Antiquity of Nations? Nations and Nationalism 13(3): 523-36.

Shin GW (2006) Ethnic nationalism in Korea. Stanford: Stanford University Press.

Smith AD (1998) Nationalism and modernism. London: Routledge. 